Meta

Journal des traducteurs

Translators' Journal

MEIPING, Zhang (2017): Jingshi Tongwenguan Waiyu Jiaoyu

Yanjiu (京师同文馆外语教育研究) [Studies on the Foreign

Language Education of the Peking Tongwen Guan]. Hangzhou:

Zhejiang University Press, 416 p.

\title{
Huabo Yang
}

Volume 64, numéro 2, août 2019

URI : https://id.erudit.org/iderudit/1068212ar

DOI : https://doi.org/10.7202/1068212ar

Aller au sommaire du numéro

Éditeur(s)

Les Presses de l'Université de Montréal

\section{ISSN}

0026-0452 (imprimé)

1492-1421 (numérique)

Découvrir la revue

Citer ce compte rendu

Yang, H. (2019). Compte rendu de [MEIPING, Zhang (2017): Jingshi Tongwenguan Waiyu Jiaoyu Yanjiu (京师同文馆外语教育研究) [Studies on the

Foreign Language Education of the Peking Tongwen Guan]. Hangzhou:

Zhejiang University Press, 416 p.] Meta, 64(2), 571-573.

https://doi.org/10.7202/1068212ar d'utilisation que vous pouvez consulter en ligne. 
use of discussion forums as a tool for reflection, self-evaluation and peer learning in a specialized English-French translation course. Finally, the last chapter shows the usefulness of using a specialized multilingual comparable corpus for the practice of translation. A comparison is made between how this can be used by the novice translator and the experienced translator. The authors argue in favor of this methodology when working with specialized texts since the quality of the translation is not only enhanced from the point of view of content but also from the perspective of the terminology and phraseology that are typically used in the field.

Overall, the different chapters of this book make it an excellent starting point both for researchers and practitioners in search of new ideas for projects and students embarking on a translation degree. The two editors of the volume, Éric Poirier and Daniel Gallego-Hernández, from the University of Québec in Trois-Rivières and Alicante University, have published extensively in this field and have successfully gathered a very insightful variety of research material in the different chapters to give valuable insight into the latest innovations in the field of financial and institutional translation. These results contribute to the existing literature and make the book an asset to scholars, students and practitioners alike.

Elena Alcalde Peñalver Universidad de Alcalá, Alcalá de Henares, Spain

MeIPING, Zhang (2017): Jingshi Tongwenguan Waiyu Jiaoyu Yanjiu (京师同文馆外语教育研 究) [Studies on the Foreign Language Education of the Peking Tongwen Guan]. Hangzhou: Zhejiang University Press, $416 \mathrm{p}$.

The Peking Tongwen Guan (京师同文馆), also known as the School of Combined Learning, T'ung-wen Kuan or Tungwen College, was established during the late Qing Dynasty when the empire was confronted with both military and diplomatic defeats. The school was officially founded in 1862 and eventually incorporated into the Imperial University of Peking (京师大学堂) in 1902, after having operated for 40 years. Its original mission was to "train the translators needed in Sino-Western diplomacy" (Guo and Liu 1978: 525) for the crumbling empire. As the first foreign language school run by the government in modern times, the establishment of Tongwen Guan not only marks the beginning of the modernization of education in China, but also initiates the practice of training interpreters and translators in modern Chinese government-funded schools (Biggerstaff 1961).
In the book under review, the author comprehensively discusses the foreign language education offered at Tongwen Guan from the perspectives of its founding, course design, schooling system, instructor recruitment, student enrolment, management, teaching and translation activities, with a special focus on the role of translation as a teaching method in training interpreters and of books of Western knowledge translated by the instructors and students at the school. In a word, this book addresses many issues with translation being only one of the foci.

The whole book is composed of eight chapters. The Introduction offers a systematic review of the academic history of Tongwen Guan. Scholars from many disciplines, especially history, have discussed its importance and influence. The author however works from the perspective of foreign language education and translation studies, which enriches the existing knowledge on Tongwen Guan (p. 30). Overall, in the last decade, the evaluation and assessment of Tongwen Guan have become more objective and studies have also increased significantly.

In Chapter 1, the author explores the underlying reasons for the establishment of Tongwen Guan and its evolution. The author argues that the establishment of this school has its internal and external causes. Internal causes include China being in a diplomatic dilemma at that time. Due to the First and Second Opium Wars, China had to train qualified interpreters and translators to negotiate with Western countries. External causes include the fact that establishing foreign language schools had been advocated and supported by progressive and openminded officials, such as Feng Guifen (冯桂芬) and Guo Songtao (郭嵩奉), so as to avert a governance crisis in the empire. Their advocacy for training interpreting and translation talents produced some positive effects in the royal court. Prince Gong (奕䜣) and other officials in power then proposed the founding of Tongwen Guan in 1861 and it was formally established in 1862 . In the early stages, only foreign languages were taught with the goal of training interpreters and translators. Later, in 1869, the former American interpreter and missionary William Alecander Parsons Martin was officially appointed the chief instructor or headmaster of the school, thanks to the recommendation of Robert Hart, the Inspector-General of China's Imperial Maritime Custom Service. With the support of Hart, Martin carried out drastic reforms and the school's situation gradually improved.

Chapter 2 describes the faculty at Tongwen Guan, including foreign and native Chinese instructors. The author gives a full account of these instructors at Tongwen Guan in terms of their recruitment, professional accomplishments 
and treatment as well as their contributions. There were 51 foreign instructors from several foreign countries and 32 native Chinese instructors in total. A noteworthy thing is that their names, nationalities, arrival dates, subjects and academic qualifications are provided in detail. Many foreign instructors had a background in interpreting or translating. Among them, W.A.P. Martin, the chief instructor, who once worked as an interpreter. He helped enormously in training other interpreters. To attract excellent foreign instructors and to show the generosity of the Qing government, foreign instructors were paid much higher than Chinese instructors. Together, they trained many talents in translation, politics, diplomacy and other fields, thus promoting the modernization of China.

Chapter 3 focuses on students at Tongwen Guan. To achieve its goal of training interpreters, translators and diplomats in a short period of time, Tongwen Guan designed very strict and indepth management models in such areas as enrolment, subsidies, attendance, studies, assessments, rewards and punishment. In terms of enrolment, to have more potential students and to recruit outstanding students, Tongwen Guan's methods were expanded from the initial selection to exams, submissions and recommendations. In terms of subsidies, students could receive a certain amount of gao huo (膏火, subsidy) every month for living expenses, and those students who performed the best on exams could immediately become officials of the empire. In addition, students had to strictly abide by the rules and regulations, and good academic results would be awarded accordingly.

Chapter 4 covers the teaching and management system as well as the organization of Tongwen Guan. The author admits frankly that "as an institution specializing in training interpreters and diplomats, Tongwen Guan's structure is very special and complex, and should be said to be unique in the history of Chinese education" (p. 161). The teaching and management system at Tongwen Guan could be divided into two levels: the administrative level and the executive level. The former mainly included the ministers of zong li ya men (总理衙门, Office in General Charge of Foreign Affairs) and the Inspector, occupied by Hart, while the latter included the chief instructor and the general instructors. In terms of teaching, Tongwen Guan had four major sectors: the French school, the Russian school, the German school and the English school. To teach students in accordance with their aptitudes and to improve the quality of teaching, students of similar age and aptitude from all the schools would be classified into one group.

Chapter 5 deals with the curriculum and teaching at Tongwen Guan. In terms of curriculum, only knowledge of foreign languages was taught at the very beginning. After 1866, many science schools, such as astronomy, mathematics, chemistry, were opened and the curriculum was thus enriched. In 1869, M.A.P. Martin set up programs of different lengths for different students, divided into either five-year or eight-year programs. In addition, students could take optional courses. In terms of teaching, originally, Tongwen Guan adopted a teaching method that focused on translation practice. Translation was the dominant method of foreign language teaching at that time and, following that trend, seven out of eight years of learning at Tongwen Guan required translation practice. During M.A.P Martin's tenure in office, the teaching practice at Tongwen Guan became more abundant. Instructors and students worked together to translate books of Western knowledge. Moreover, students began to act as on-duty interpreters for foreign affairs activities, translated or proofread diplomatic documents, served as interns in Chinese embassies and even studied abroad.

Chapter 6 analyzes the great turning point for the school - the debate over Western learning among officials of high ranks. In its early days, the Westernization School decided to carry out further reforms, setting up a tian wen suan xue guan (天文算学馆, School of Astronomy and Mathematics) and enrolled the bureaucratic class to study Western knowledge, which aroused fierce opposition from the die-hard Conservative School, eventually leading to "the first controversy about learning Western knowledge in modern China" (p. 248). The controversy ended in the Westernization School's victory, which enabled Tongwen Guan to set up new schools to disseminate Western knowledge as well as to carry out reforms in student enrolment and foreign instructor recruitment.

Chapter 7 focuses on the translation of Western knowledge at Tongwen Guan and its influence. Translation activities at Tongwen Guan were led by M.A.P. Martin. They are seen as "the beginning of the systematic translation of Western knowledge in modern Chinese government-run institutions" (p. 279). The reasons why Tongwen Guan translated Western knowledge were, on the one hand, the realistic and urgent need that zong li ya men had for translations of relevant works of international law for negotiations with the West as well as for textbooks for educational use. On the other hand, translation itself was an important part of the curriculum and also an important teaching method in the school. With the cooperation of instructors and students, at least 32 books of Western knowledge were translated, covering subjects such as law, economics, linguistics and natural sciences, which were conducive to enlightening the Chinese people and popularizing Western knowledge in China. However, there were still problems 
with these translations, such as the limited range of material selected and the inferior quality of the translations (p. 325). Moreover, compared to another government-funded translation department in the Jiangnan Arsenal (Lung 2016), the books translated by Tongwen Guan were limited and subject-biased.

Chapter 8 concludes the book by summarizing Tongwen Guan's achievements and influence. In this chapter, the author outlines Tongwen Guan's influence in the fields of diplomacy, military and political affairs, education and culture, fully affirming its contribution to the cultivation of "the first generation of modern knowledge and bilingual talents" (p. 331), of which translation plays a significant role. At the same time, the author also points out problems, such as the chaos and disorder in the school's management. Finally, the author emphasizes the beneficial inspiration of this school, such as "cultivating translators with diplomatic ability and international perspective" (p. 366).

This book, as a summarized work in the study of foreign language education, the training of translators and translation activities at Tongwen Guan, has the following merits. The first is to fill some gaps in the existing research. For example, the study of foreign instructors at Tongwen Guan is much more thorough, while the study of native Chinese instructors is "not yet discussed in a specific article" (p. 24), so accounts of the recruitment, treatment and other aspects of Chinese instructors fill a gap in this field of research. The second is that some studies in this book are much more in-depth. For example, in view of the reasons for the establishment of Tongwen Guan, most of the previous studies are incomplete, while this book makes a comprehensive and detailed summary of both internal and external causes. And the third is in the research methods. This book expands the sources of academic literature, not only making full use of historical Chinese materials, but also attaching great importance to foreign documents, exploring and utilizing some of the previously neglected materials in foreign languages.
However, the book also has some shortcomings. For example, although it is concerned about the foreign language education at Tongwen Guan, the education and translation of French, Russian, German, Japanese and other languages have not been given as much attention as English. In addition, although the book emphasizes the importance of Tongwen Guan in promoting the modernization of China, it seems that the book has failed to elaborate on the essence of modernization and its concrete manifestations. Finally, the Index section of the book is underdeveloped, providing only twelve items (names and nouns), while the more than 400-page book contains numerous characters and keywords which will be difficult for users to retrieve. Nevertheless, this book, as the latest monograph on foreign language education and translation studies at Tongwen Guan, has reached a new height in historical material mining and summarizing the existing research. It fully presents all aspects of foreign language education and translation studies in the earliest modern government school in China. In short, not only is it an important reference book for studies on the history of foreign language education, translation activities and the training of interpreters and translators during the late Qing Dynasty, it can also shed some light on today's translation education.

Huabo YANG Xiamen University, Xiamen, China

\section{REFERENCES}

Biggerstaff, Knight (1961): The Earliest Modern Government Schools in China. New York: Cornell University Press.

Guo, Ting-Yee and Liu, Kwang-Ching (1978): Selfstrengthening: the pursuit of Western technology. In: John K. FaIrbank, ed. The Cambridge History of China. Vol. 10. Late Ch'ing 18001911. Cambridge: Cambridge University Press, 491-542.

Lung, Rachel (2016): The Jiangnan Arsenal: A Microcosm of Translation and Ideological Transformation in 19th-century China. Meta. 61(HS):37-52. 